\title{
Toxicity and Physical Properties of Atrazine and its Degradation Products: \\ A Literature Survey
}

\author{
Kathleen C. Pugh, Ph.D.
}

Waste Management and Remediation

Environmental Research Center

Muscle Shoals, Alabama 


\section{DISCLAIMER}

This report was prepared as an account of work sponsored by an agency of the United States Government. Neither the United States Government nor any agency thereof, nor any of their employees, make any warranty, express or implied, or assumes any legal liability or responsibility for the accuracy, completeness, or usefulness of any information, apparatus, product, or process disclosed, or represents that its use would not infringe privately owned rights. Reference herein to any specific commercial product, process, or service by trade name, trademark, manufacturer, or otherwise does not necessarily constitute or imply its endorsement, recommendation, or favoring by the United States Government or any agency thereof. The views and opinions of authors expressed herein do not necessarily state or reflect those of the United States Government or any agency thereof. 


\section{DISCLAIMER}

Portions of this document may be illegible in electronic image products. Images are produced from the best available original document. 


\section{Contents}

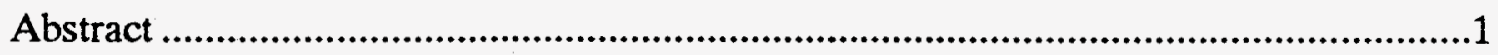

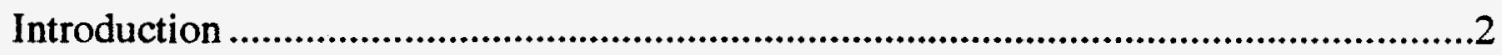

Part 1: Toxicity of Atrazine and its Degradation Products......................................4

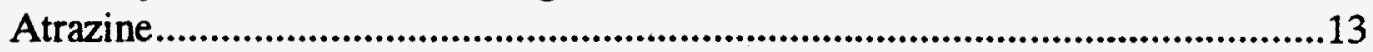

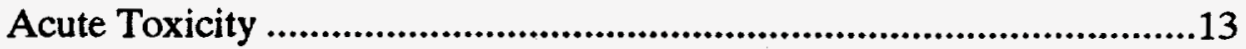

Fish Toxicity .................................................................................13

Chronic Toxicity ........................................................................13

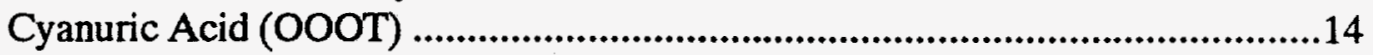

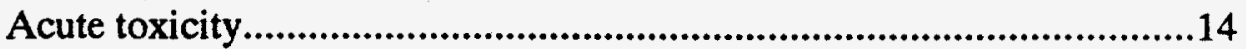

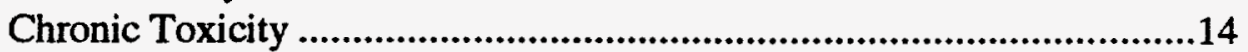

Carcinogenic Effects .............................................................14

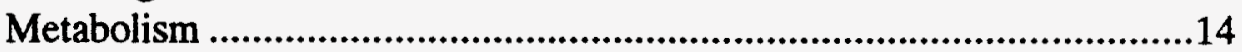

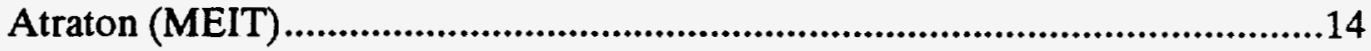

Comparison of Toxicities ............................................................................15

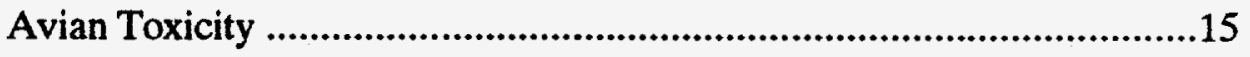

Microorganism Toxicity .......................................................16

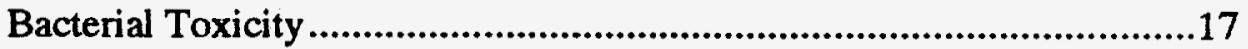

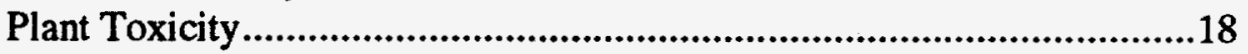

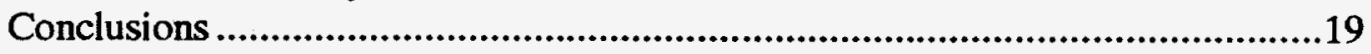

Part 2: Physical Properties of Atrazine and Its Degradation Products..........................20

Melting Point and Molecular Weight ..............................................20

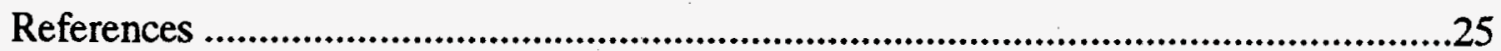




\section{Tables}

Table I. Toxicity Rating Chart ................................................................................

Table II. Approximate Oral Acute $\mathrm{LD}_{50} \mathrm{~s}$ in Rodents .................................................

Table III. Atrazine and Degradation Products...............................................................6

Table IV. Relevant Data for Avian Toxicity and Repellancy........................................15

Table V. Summary of Toxicity Data for $s$-Triazines Toward

Phototrophic Microorganisms....................................................................................17

Table VI. Summary of Toxicities Toward Bioluminescent

Bacteria as Determined by Microtox ........................................................................18

Table VII. Melting Point and Molecular Weight of Atrazine and Thirteen of Its Degradation Products................................................................21

Table VIII. Vapor Pressure and Solubility of Atrazine and

Nine of Its Degradation Products..............................................................................22

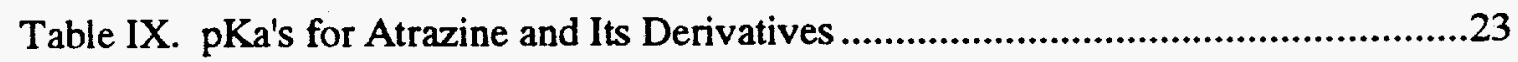

Table X. UV, IR, and Mass Spec Data Sources ………............................................24

Table XI. Half-Lives for Atrazine and Its Degradation Products in Soil and During $\mathrm{TiO}_{2}$ Photocatalysis.................................................................24

\section{Figure}

Figure 1: $\mathrm{TiO}_{2}$ Photocatalytic Degradation of Atrazine

Proposed by Pelizzetti and Coworkers......................................................................... 


\title{
Toxicity and Physical Properties of Atrazine and its Degradation Products: A Literature Survey
}

\begin{abstract}
The Tennessee Valley Authority's Environmental Research Center has been developing a means of detoxifying atrazine waste waters using $\mathrm{TiO}_{2}$ photocatalysis. The toxicity and physical properties of atrazine and its degradation products will probably be required information in obtaining permits from the United States Environmental Protection Agency for the demonstration of any photocatalytic treatment of atrazine waste waters. The following report is a literature survey of the toxicological and physical properties of atrazine and its degradation products.
\end{abstract}

\section{Part 1. Toxicity of Atrazine and its Degradation Products}

In the studies reviewed in this report, atrazine was reported to be more toxic than its degradation products. Atrazine has been reported to have higher chronic toxicity than CIAT towards rat endocrine activity. The degradation product CAAT was less toxic than $s$-triazine (the ring system of triazines) towards birds. For phototrophic microorganisms, the order of toxicity from high to low was: atrazine>CIAT>CEAT. The degradation products OIET and CAAT were found to be nontoxic towards most phototrophic microorganism cultures tested. The Microtox test of bacterial toxicity also showed that atrazine was more toxic than its degradation products with the order of toxicity from high to low reported as: atrazine $>$ CEAT $>$ CIAT. The end product of $\mathrm{TiO}_{2}$ photocatalytic degradation of atrazine is cyanuric acid (OOOT). Atrazine $\left(\mathrm{LD}_{50} 3.0 \mathrm{~g} / \mathrm{kg}\right)$ is more than twice as toxic as cyanuric acid $\left(\mathrm{LD}_{50} 7.7 \mathrm{~g} / \mathrm{kg}\right)$. Based on the literature currently available, it appears that any degradation of atrazine results in less toxic products. Complete degradation of atrazine to cyanuric acid, which can be accomplished using $\mathrm{TiO}_{2}$ photocatalysis, decreases the toxicity of the waste stream to less than half its original toxicity.

\section{Part 2. Physical Properties of Atrazine and its Degradation Products}

The physical properties of atrazine and its degradation products reviewed in Part 2 of this report include melting point, molecular weight, vapor pressure, solubility, and pKa's. Sources for UV, IR, and mass spectral data are also reported. The soil half-lives for atrazine, CIAT, and CEAT are compared to the $\mathrm{TiO}_{2}$ photocatalytic half-lives for the same compounds. (27 pp)

Key Words: atrazine, degradation products, melting point, physical properties, solubility, $\mathrm{TiO}_{2}$, toxicity, vapor pressure 


\section{Introduction}

The Tennessee Valley Authority's Environmental Research Center has been the site of research to develop a means of detoxifying atrazine waste waters using $\mathrm{TiO}_{2}$ photocatalysis. ${ }^{1}$ The toxicity and physical properties of atrazine and its degradation products will probably be required information in obtaining permits from the United States Environmental Protection Agency for the demonstration of any photocatalytic treatment process for atrazine waste waters.

The following is a literature survey of the toxicological and physical properties of atrazine and some of its identified and potential degradation products. A number of the degradation products have been identified during atrazine photocatalysis using $\mathrm{TiO}_{2}$. Others have been identified as atrazine degradation products in other systems and may later be identified as $\mathrm{TiO}_{2}$ photocatalysis products. The $\mathrm{TiO}_{2}$ photocatalytic degradation products identified by Pelizetti and coworkers are shown in the degradation mechanism in Figure 1.2

The nomenclature system of Cook, ${ }^{3}$ Adams, ${ }^{4}$ and Hapeman-Somich ${ }^{5}$ is used to label compounds: $\mathrm{A}$, amino; C, chloro; E, ethylamino; I, isopropylamino; $\mathrm{O}$, hydroxy; $\mathrm{T}$, triazine ring. Other abbreviations include $\mathrm{D}$, acetamido, and $\mathrm{M}$, methoxy.

This report is separated into two parts. Part 1 reports literature information on the toxicity of atrazine and its degradation products. Information was not available for some degradation products. This may be due to the fact that certain degradation products have not yet been assigned Chemical Abstracts Service (CAS) Registry Numbers. The Registry of Toxic Effects of Chemical Substances (RTECS) was also searched for data on atrazine and its degradation products. For those compounds for which data could be obtained, the $\mathrm{LD}_{50}$ (lethal dose for $50 \%$ of test subjects, usually rats or mice) is given when reported. Other available toxicological information is also reviewed in Part 1.

Part 2 of this report summarizes the physical properties of atrazine and its degradation products. These properties include melting point, molecular weight, vapor pressure, solubility data, pKas and soil metabolism rates when available. 


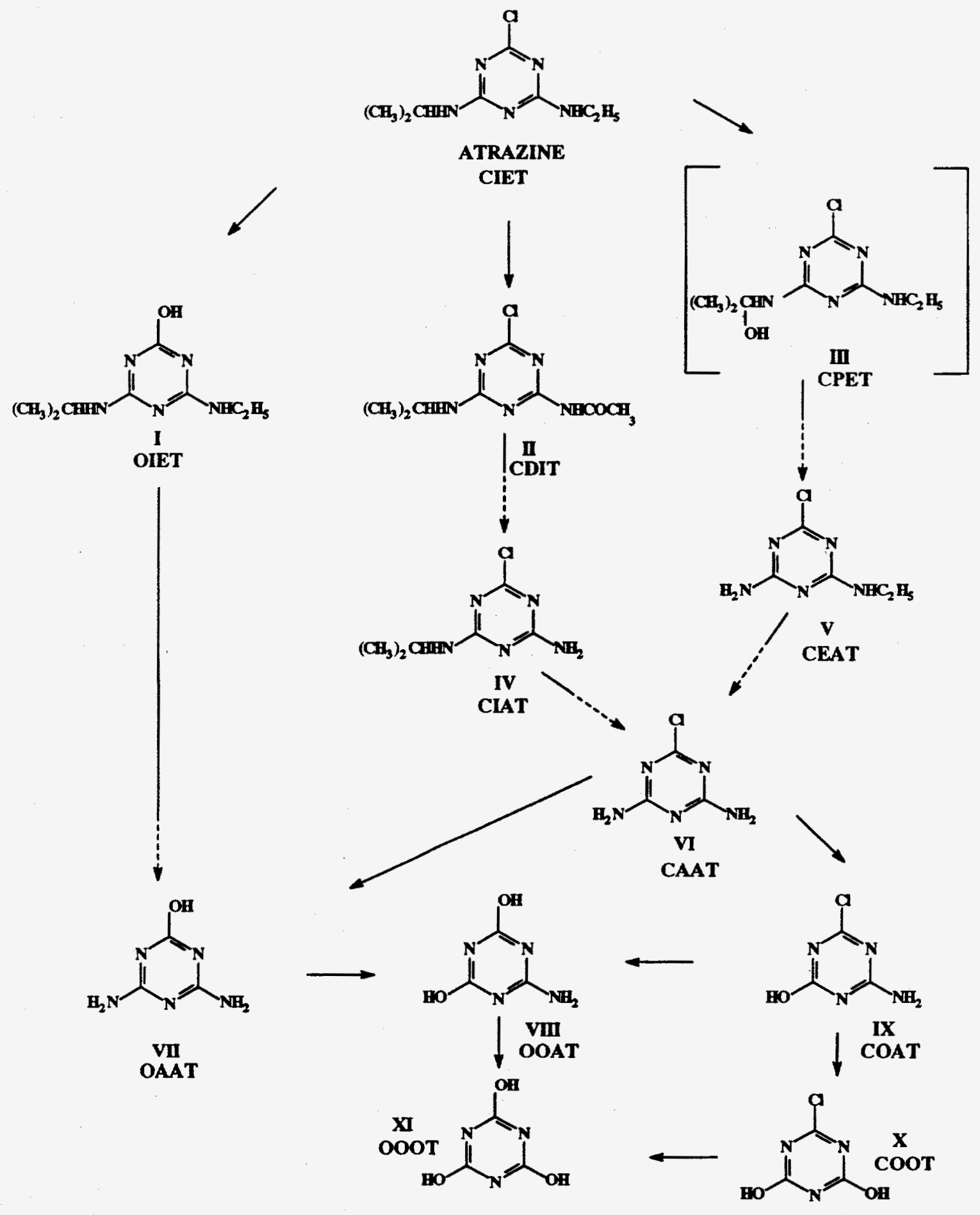

Figure 1. $\mathrm{TiO}_{2}$ Photocatalytic Degradation of Atrazine Proposed by Pelizzetti and Coworkers. ${ }^{2}$ 


\section{Part 1: Toxicity of Atrazine and its Degradation Products}

For the purpose of providing background information for an audience less familiar with toxicology, Table I gives commonly accepted classifications of toxicity ratings. To put these classifications into perspective, Table II lists the Lethal Dose for $50 \%$ of Subjects $\left(\mathrm{LD}_{50}\right)$ for some well known chemicals. These charts were provided by the PACS consulting firm, courtesy of Dr. Henry Nowicki. 6

Toxicity data for atrazine and cyanuric acid was relatively abundant. However, little or no data was available for most of the degradation products. In some cases, the CAS Registry number has not yet been assigned to the degradation product, so a computer search was not possible. A search by chemical name was difficult because the nomenclature for atrazine derivatives varies from paper to paper.

Some of the studies reviewed here reported the toxicity of a degradation product in a nonmammalian test and therefore no $\mathrm{LD}_{50}$ was established for many of the atrazine degradation products. Table III is a compilation of the compound name, its four letter acronym, any known synonyms, its structure, CAS Registry Number, RTECS Number, and $\mathrm{LD}_{50}$ for the cases in which data was available.

Table I. Toxicity Rating Chart ${ }^{6}$

Toxicity rating or class
Probable oral lethal dose

for humans, $\mathrm{mg} / \mathrm{kg}$ a
Practically nontoxic

Slightly toxic

Moderately toxic

Very toxic

Extremely toxic

Super-toxic
$>15,000$

$5,000-15,000$

$500-5000$

$50-500$

$5-50$

$<5$

andicates lethal dose for $50 \%$ of subjects. 
Table II. Approximate Oral Acute $\mathrm{LD}_{50}$ s in Rodents
Agent
$\mathrm{LD}_{50}(\mathrm{mg} / \mathrm{kg})$

Sodium chloride

(table salt)

Ferrous sulfate

1,520

(prescribed for anemia)

2,4-D (a weed killer) 368

DDT

135

(an insecticide no longer used)

Caffeine

(in coffee)

Nicotine

(in tobacco)

Strychnine sulfate

(used to kill pests)

Botulinus toxin

0.01

(in spoiled food) 
Table III. Atrazine and Degradation Products

Name(s) Structure $\quad \mathrm{LD}_{50}(\mathrm{mg} / \mathrm{kg})$

Atrazine<smiles>CCNc1nc(Cl)nc(NC(C)C)n1</smiles>

\section{CIET}

(2-Chloro-4-ethylamino-6-isopropylamino-s-triazine)

(6-Chloro-N-ethyl-N'-(1-methylethyl)-1,3,5-triazine-2,4-diamine)

Aatrex, Gesaprim, G30027, Atratol

CAS No. 1912-24-9

1750 , oral, mouse ${ }^{7}$

RTECS No. XY5600000

3000 , oral, rat $^{7}$

\section{Cyanuric Acid}<smiles>Oc1nc(O)nc(O)n1</smiles>

\section{OOOT}

(Isocyanuric acid)

(2,4,6-Trihydroxy-s-triazine)

CAS No. 108-80-5

RTECS No. XZ1800000

3400 , oral, mouse 8

7700 , oral, rat $^{8}$

$>500$, ivn, ${ }^{\mathrm{a}}$ mouse ${ }^{8}$

$>100$, ivn, rat ${ }^{8}$

antravenous administration. 
Table III (continued). Atrazine and Degradation Products
Name(s)
Structure
$\mathrm{LD}_{50}(\mathrm{mg} / \mathrm{kg})$

Atrazine desisopropyl<smiles>CCNc1nc(N)nc(Cl)n1</smiles>

\section{CEAT}

(2-Amino-4-chloro-6-ethylamino-s-triazine)

(6-Chloro-N-ethyl-1,3,5-triazine-2,4-diamine)

(2,4-Diamino-6-chloro-N-ethyl-1,3,5-triazine)

CAS No. 1007-28-9

RTECS No. unknown

Atrazine desethyl<smiles>CC(C)Nc1nc(N)nc(Cl)n1</smiles>

\section{CIAT}

(2-Amino-4-chloro-6-isopropylamino-s-triazine)

(4-Amino-2-chloro-6-isopropylamino-s-triazine)

(6-Chloro-N-(1-methylethyl)-1,3,5-triazine-2,4-diamine)

(2,4-Diamino-6-chloro-N-(1-methylethyl)-1,3,5-triazine)

CAS No. 6190-65-4

RTECS No. unknown 
Table III (continued). Atrazine and Degradation Products

Name(s) Structure $\quad \mathrm{LD}_{50}(\mathrm{mg} / \mathrm{kg})$

2-chloro-4,6-diamino-s-triazine<smiles>Nc1nc(N)nc(Cl)n1</smiles>

\section{CAAT}

(Didealkylatedatrazine)

(2,4-Diamino-6-chloro-1,3,5-triazine)

CAS No. 3397-62-4

RTECS No. unknown

Ammeline<smiles>Nc1nc(N)nc(O)n1</smiles>

OAAT

(2,4-Diamino-6-hydroxy-s-triazine)

(Atrazine desethyl desisopropyl-2-hydroxy)

(4,6-Diamino-1,3,5-triazine-2(1H)-one)

[s-Triazin-2-ol, 4,6-diamino-(8CI)]

[1,3,5-Triazin-2(1H)-one, 4,6-diamino-(9CI)]

CAS No. 645-92-1

RTECS No. unknown 
Table III (continued). Atrazine and Degradation Products

Name(s) Structure $\quad \mathrm{LD}_{50}(\mathrm{mg} / \mathrm{kg})$

\section{Ammelide $^{9}$}<smiles>Nc1nc(O)nc(O)n1</smiles>

OOAT

(2-Amino-4,6-dihydroxy-s-triazine)

(6-Amino-1,3,5-triazine-2,4(1H,3H)-dione)

(1,3,5-Triazine-2,4(1H,3H)-dione, 6-amino-)

CAS No. 645-93-2

RTECS No. unknown

Hydroxyatrazine<smiles>CCNc1nc(O)nc(NC(C)C)n1</smiles>

OIET

(Atrazine-2-hydroxy)

(4-(Ethylamino)-2-hydroxy-6-isopropylamino-s-triazine)

(2-Hydroxy-4-ethylamino-6-isopropylamino-s-triazine)

(4-(Ethylamino)-6-[1-methylethyl]amino-1,3,5-triazine-2-(1H)one)

(2-Ethylamino-4-hydroxy-6-isopropylamino-s-triazine)

(2,4-Diamino-6-hydroxy-N-ethyl-N'(methylethyl)-1,3,5-triazine)

CAS No. 2163-68-0

RTECS No. unknown 
Table III (continued). Atrazine and Degradation Products

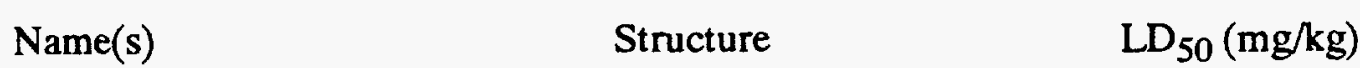

2-Amino-4-hydroxy-6-isopropylamino-s-triazine<smiles>CC(C)Nc1nc(N)nc(O)n1</smiles>

\section{OAIT}

(4-Amino-6-[(1-methylethyl)amino]-1,3,5-triazine-2(1H)-one)

(N-Isopropylammeline)

(Atrazine desethyl-2-hydroxy)

(4-Amino-2-hydroxy-6-isopropylamino-s-triazine)

CAS No. unknown

RTECS No. unknown

\section{2-Amino-4-ethylamino-6-hydroxy-s-triazine}<smiles>CCNc1nc(N)nc(O)n1</smiles>

\section{OAET}

(4-Amino-6-(ethylamino)-1,3,5-triazine-2(1H)-one)

(N-ethylammeline)

CAS No. unknown

RTECS No. unknown 
Table III (continued). Atrazine and Degradation Products

$\mathrm{Name}(\mathrm{s}) \quad$ Structure $\quad \mathrm{LD}_{50}(\mathrm{mg} / \mathrm{kg})$

\section{Atraton}<smiles>CCNc1nc(NC(C)C)nc(OC)n1</smiles>

\section{MEIT}

(2-Methoxy atrazine)

(2-[Ethylamino]-4-[isopropylamino]-6-methoxy-s-triazine)

(Gestamine)

CAS No. 1610-17-9

RTECS No. XY8750000

1465 , oral, rat or mouse 10

2-amino-4-chloro-6-hydroxy-s-triazine<smiles>Nc1nc(O)nc(Cl)n1</smiles>

COAT

CAS No. unknown

RTECS No. unknown 
Table III (concluded). Atrazine and Degradation Products

Name(s)

Structure

$\mathrm{LD}_{50}(\mathrm{mg} / \mathrm{kg})$

2-chloro-4,6-dihydroxy-s-triazine<smiles>Oc1nc(O)nc(Cl)n1</smiles>

\section{COOT}

CAS No. unknown

RTECS No. unknown 


\section{Atrazine}

A search of the CAS and Beilstein databases for "atrazine" cross referenced with "toxicity" led to 460 references. The information from only a select few of these references will be presented here.

The Material Safety Data Sheets (MSDS) for atrazine and its degradation products were provided by the suppliers: Aldrich (Milwuakee, WI), Supelco (Bellefonte, PA), Chem Service (West Chester, PA), and Ciba-Geigy, Inc. (Greensboro, NC).

\section{Acute Toxicity}

Target organs for atrazine include skin, eyes, mucous membranes, respiratory system, kidneys, and liver. ${ }^{11,12}$

Most MSDSs for atrazine list the $\mathrm{LD}_{50}$ (oral, rat or mouse) as $1750 \mathrm{mg} / \mathrm{kg}$. Ciba-Geigy's MSDS reports a $\mathrm{LD}_{50}$ of $3090 \mathrm{mg} / \mathrm{kg}$ (oral, rat), $>3,100 \mathrm{mg} / \mathrm{kg}$ (dermal, rat), and a $\mathrm{LC}_{50}$ of $1.8 \mathrm{mg} / \mathrm{L}$ air 4 hours (inhalation, rat). The Handbook of Toxic and Hazardous Chemicals, 3rd ed., ${ }^{7}$ reports a $\mathrm{LD}_{50}$ of $1750 \mathrm{mg} / \mathrm{kg}$ (oral, mouse) and $3000 \mathrm{mg} / \mathrm{kg}$ (oral, rat), but notes that the purity of the compounds in these studies was not specified. The Registry of Toxic Effects of Chemical Substances (RTECS) lists a $\mathrm{LD}_{50}$ of $672 \mathrm{mg} / \mathrm{kg}$ (oral, rat) and $850 \mathrm{mg} / \mathrm{kg}$ (oral, mouse) for atrazine, ${ }^{11}$ according to a National Toxicology Program report. ${ }^{12}$

\section{Fish Toxicity}

An investigation of acute and subacute toxicity of atrazine on Carp (Cyprinus carpio L.) was performed by Neskovic and coworkers. ${ }^{13}$ These researchers reported that atrazine is only slightly toxic to Carp according to its $\mathrm{LC}_{50}$, but provokes certain biochemical and histopathological changes in some organs and tissues of fish. The most pronounced effects are on the AP (alkaline phosphatase) activity in the serum and some organs. Cell changes were most pronounced in the gills and the liver.

\section{Chronic Toxicity}

The chronic toxicity of atrazine was discussed in Ciba-Geigy's MSDS. Atrazine has been shown to cause an increased incidence of mammary tumors in female Sprague-Dawley rats during longterm feeding studies. Atrazine also causes cardiotoxicity in dogs and mice. According to CibaGeigy, some studies which showed mutagenic effects of atrazine on barley seeds and com plants were later successfully refuted (no references). However, a National Toxicology Report, ${ }^{12}$ referring to the RTECS entry for atrazine, ${ }^{11}$ lists atrazine as a mutagen, tumorigen, and reproductive abnormality inducer.

The Handbook of Toxic and Hazardous Chemicals, $3 r d$ ed., ${ }^{7}$ reported that toxicity data on atrazine were reviewed by the National Academy of Sciences and were used to identify a chronic NOAEL (No Adverse Effects Level) of $21.5 \mathrm{mg} / \mathrm{kg} /$ day. Although at that time it was concluded that atrazine has low chronic toxicity, an uncertainty factor of 1,000 was employed in calculation of the ADI (acceptable daily intake) since only limited data were available. The resulting value 
$(0.021 \mathrm{mg} / \mathrm{kg} / \mathrm{day})$ corresponds to an $\mathrm{ADI}$ of $0.73 \mathrm{mg} / \mathrm{L}$ in a $70-\mathrm{kg}$ adult consuming $2 \mathrm{~L}$ of water per day.

\section{Cyanuric Acid (OOOT)}

\section{Acute toxicity}

Unlike atrazine, cyanuric acid (OOOT) is practically nontoxic when administered as a single oral or dermal dose. ${ }^{14}$ Hammond and coworkers reported a $\mathrm{LD}_{50}$ (oral, rat) of $>10 \mathrm{~g} / \mathrm{kg},{ }^{14}$ but an earlier report sited the $\mathrm{LD}_{50}$ (oral, rat) as $>5.00 \mathrm{~g} / \mathrm{kg}$. ${ }^{15}$ The RTECS entry for OOOT listed the $\mathrm{LD}_{50}$ (oral, rat) as $7.7 \mathrm{~g} / \mathrm{kg}$ and the $\mathrm{LD}_{50}$ (oral, mouse) as $3.4 \mathrm{~g} / \mathrm{kg}$. The dermal rabbit $\mathrm{LD}_{50}$ for OOOT was reported as $>7.94 \mathrm{~g} / \mathrm{kg} .{ }^{14}$ The Federal Hazardous Substances Act Test (rabbit, eye) was $1.5 / 110$, which led to the classification of OOOT as a slight irritant. OOOT has been shown to be poorly absorbed when applied dermally. ${ }^{16}$ OOOT is very toxic towards certain types of barley and radishes. ${ }^{17}$

\section{Chronic Toxicity}

The chronic toxic effects of OOOT were reviewed by Canelli in $1974 .^{18}$ At a dose of 30 $\mathrm{mg} / \mathrm{kg} /$ day, dystrophic changes in the kidneys of guinea pigs and rats were observed. However, at a lower dose of $10 \mathrm{mg} / \mathrm{kg} /$ day, no changes in kidney tissue were observed..$^{15,19}$

\section{Carcinogenic Effects}

A low blastomogenic effect in rats and mice (tumors after 18 months) due to administration of OOOT has been reported, but adequate controls were not part of this study and benzene and oil were used to administer some doses. ${ }^{20}$ The RTECS entry for OOOT gave the status of "equivocal tumorigenic agent" for all RTECS criteria. ${ }^{11}$

\section{Metabolism}

OOOT has been shown to be readily eliminated from the body unchanged. ${ }^{14}$ Studies in which rats were given both oral and intravenous administration of OOOT demonstrated that OOOT is excreted, primarily in urine, unchanged. ${ }^{21}$ No bioaccumulation of radiolabeled OOOT was observed.

\section{Atraton (MEIT)}

Although atraton (MEIT) is not one of the degradation products generated during $\mathrm{TiO}_{2}$ photocatalysis of atrazine, ${ }^{22}$ it is a common soil metabolite of atrazine. A LD 50 of $1465 \mathrm{mg} / \mathrm{kg}$ (oral, rat) for this compound was reported on the Chem Service, Inc. MSDS. The RTECS entry for MEIT listed a $L D_{50}$ (oral, rat) of $1465 \mathrm{mg} / \mathrm{kg}$ and a $L D_{50}$ (oral, mouse) of $905 \mathrm{mg} / \mathrm{kg}$. Several studies have been done to try to predict the relative toxicity of atraton using quantitative 
structure-activity relationships (QSAR's). ${ }^{23}$ Because the data in these studies has not been experimentally verified, it will not be presented here.

\section{Comparison of Toxicities}

Although there is an abundance of mammalian toxicity data on atrazine and cyanuric acid, many of the other degradation products of atrazine have no mammalian toxicological data. One exception is a study which compared the toxicity of atrazine to one of its degradation products, CIAT, in the endocrine system of rats. ${ }^{24}$ The gonadotropic systems of rat offspring were found to develop more slowly when mother rats were treated with atrazine during pregnancy and lactation. These observations were the result of alteration of 5-alpha-R activity in the anterior of the pituitary gland and inhibition of the 5-alpha-DHT prostate receptor. CIAT also influenced activities of hormones in the anterior of the pituitary gland, and significantly increased the weight of the gland. However, the researchers concluded that the parent compound, atrazine, exhibited more significant chronic effects than did CIAT. ${ }^{24,25}$

Despite the paucity of studies comparing the toxicity of atrazine and its degradation products in mammalian systems, such studies have been carried out using species other than mammals. The toxicity of atrazine and its degradation products was compared in studies using domestic and wild birds, ${ }^{26}$ phototropic microorganisms, ${ }^{27}$ bacteria (Microtox), ${ }^{28}$ and certain plants. ${ }^{29}$ Summaries of those studies follows.

\section{Avian Toxicity}

An evaluation of 998 chemicals for avian toxicity, stupefaction, and/or repellency was conducted by the Wildlife Research Center in Denver, CO.26 Included in the study were the chemicals striazine (the basic ring system for triazine pesticides, including atrazine) and CAAT. The relevant data are summarized in Table IV.

Table IV. Relevant Data for Avian Toxicity and Repellancy ${ }^{26}$

\begin{tabular}{llllllll}
\hline & $\begin{array}{l}\text { Registry } \\
\text { number } \\
\text { Name }\end{array}$ & $\begin{array}{l}\mathrm{LD}_{50} \\
(\mathrm{mg} / \mathrm{kg})\end{array}$ & $\begin{array}{l}\text { Redwinged } \\
\text { blackbird } \\
\mathrm{R}_{50}\end{array}$ & $\begin{array}{l}\mathrm{R}_{50} \\
(\mathrm{mg} / \mathrm{kg})\end{array}$ & $\begin{array}{l}\text { Hazard } \\
\text { factor }^{\mathrm{b}}\end{array}$ & $\begin{array}{l}\text { Starling } \\
\mathrm{LD}_{50} \\
(\mathrm{mg} / \mathrm{kg})\end{array}$ & $\begin{array}{l}\text { Coturnix } \\
\mathrm{LD}_{50} \\
(\mathrm{mg} / \mathrm{kg})\end{array}$ \\
\hline s-Triazine & 290879 & 100 & $>1.00$ & $>76.9$ & $<0.769$ & $\ldots$ & 237 \\
CAAT & $3397624^{c}$ & $>100$ & $>1.00$ & $\ldots-\ldots$ & $\ldots$ & $\ldots$ & $>316$ \\
\hline
\end{tabular}

The data in Table IV were chosen from data in Reference 26.

bCalculated by dividing the $R_{50}$ (maximum value) by the $\mathrm{LD}_{50}$.

cMistakenly listed in Reference 26 as 3797624. 
The "Hazard Factor" listed in Table IV is a repellency-toxicity index and was calculated by assuming that at a $\mathrm{R}_{50}$ (i.e., concentration at which $50 \%$ of the birds were repelled), a bird would eat half of its maximum food intake. The amount of food a bird would eat at $50 \%$ repellency (in $\mathrm{mg} / \mathrm{kg}$ ) was then when divided by the $\mathrm{LD}_{50}$ (in $\mathrm{mg} / \mathrm{kg}$ ), to provide an index for likelihood of acute oral poisoning in the wild. An index value of $>1.00$ indicates well-accepted toxic agents which have definite potential for causing acute poisoning episodes.

The data in Table IV show that the basic s-triazine ring structure has a lower general $\mathrm{LD}_{50}$ than CAAT. This indicates that CAAT is less acutely toxic than the s-triazine ring structure towards birds. The $\mathrm{LD}_{50}$ of CAAT was also higher than that of the $s$-triazine ring for one particular species, Coturnix. Unfortunately, not enough data was available to compare the hazard factors for CAAT and the triazine ring system. However, the triazine ring system was determined to have a hazard factor of $<0.769$, indicating possible potential for causing acute poisoning episodes in the wild.

\section{Microorganism Toxicity}

In another study entitled "Effects of the Herbicide Atrazine and its Degradation Products, Alone and in Combination, on Phototrophic Microorganisms,"27 the toxicity of atrazine, CEAT, CIAT, CAAT, and OIET towards phototrophic microorganisms was examined. The author evaluated the toxic effects of the above-mentioned compounds for growth, photosynthesis, and nitrogenase activity (acetylene-reducing ability) of two species of green and three species of cyanobacteria. Atrazine was significantly more toxic than its degradation products toward the above test criteria. Table V contains a summary of the data from this paper. In general, the toxicities were: atrazine $>$ CIAT $>$ CEAT. The compounds OIET and CAAT were found to be nontoxic towards most of the cultures tested. 
Table V. Summary of Toxicity Data for s-Triazines Toward Phototrophic Microorganisms ${ }^{27}$

Name

$\mathrm{EC}_{50}(\mathrm{ppm}$ or ug/mL)

Test

$\begin{array}{lll}\text { Atrazine } & \begin{array}{l}0.1-0.5 \\ 0.03-5.0\end{array} & \begin{array}{l}\text { Photosynthesis } \\ \text { Growth } \\ \text { Acetylene Reduction }\end{array} \\ \text { CIAT } & \begin{array}{l}\mathbf{b}+1-15 \\ 1.0-8.5\end{array} & \begin{array}{l}\text { Photosynthesis } \\ \text { Growth }\end{array} \\ \text { CEAT } & 3.6-9.3 & \begin{array}{l}\text { Photosynthesis } \\ \text { Growth }\end{array} \\ \text { OIET } & 2.5->10 & \text { Photosynthesis, growth } \\ \text { CAAT } & \text { nontoxic } & \text { Photosynthesis, growth }\end{array}$

${ }^{\mathrm{a}} \mathrm{The}$ term $\mathrm{EC}_{50}$ refers to the effective concentration which elicits a $50 \%$ inhibition of the test parameter in question, calculated with reference to activity in appropriate control systems. bor cyanobacteria only atrazine had an effect. Cyanobacteria were insensitive to the other compounds.

\section{Bacterial Toxicity}

The Microtox method of toxicity assessment was performed on atrazine and two of its environmental metabolites: CIAT and CEAT. ${ }^{28}$ Microtox is a system manufactured by Microbics Corporation which utilizes a photomultiplier tube to measure light from bioluminescent bacteria. Although the mechanism of toxicity is not determined by this test, a relative assessment of toxicity is determined by measuring inhibition of light production by certain microorganisms. The study showed that CIAT and CEAT were less toxic than their parent compound, atrazine. The relevant data from this study are summarized in Table VI. 
Table VI. Summary of Toxicities Toward Bioluminescent Bacteria as Determined by Microtox 28

\begin{tabular}{ccccc}
\hline \multirow{2}{*}{ Name } & Time (min) & $\mathrm{EC}_{10^{\mathrm{a}}}$ & $\mathrm{EC}_{20^{\mathrm{a}}}$ & $\mathrm{EC}_{50^{\mathrm{a}}}$ \\
\hline \multirow{2}{*}{ Atrazine } & 5 & 13.0 & 25.8 & $95^{\mathrm{b}}$ \\
& 15 & 14.4 & 22.6 & $\sim 40^{\mathrm{b}}$ \\
& 30 & 17.5 & 24.0 & $\sim 25^{\mathrm{b}}$ \\
& 5 & 44.0 & 107.0 & $\sim 400^{\mathrm{b}}$ \\
& 15 & 63.0 & 109.0 & $\sim 305^{\mathrm{b}}$ \\
& 30 & 75.0 & 116.0 & $\sim 290^{\mathrm{b}}$ \\
& 5 & 70.0 & 180.0 & $\sim 700^{\mathrm{b}}$ \\
CEAT & 15 & 101.0 & 193.0 & $\sim 580^{\mathrm{b}}$ \\
& 30 & 134.0 & 220.0 & $\sim 580^{\mathrm{b}}$ \\
\hline
\end{tabular}

aECx is the effective concentration at which light produced by the bacteria is reduced by $x$ percentage.

bValues were read from a graph and are not necessarily accurate.

The low toxicities of atrazine, CIAT, and CEAT toward the bacteria in question led the researchers to report $\mathrm{EC}_{10}$ and $\mathrm{EC}_{20}$ values in addition to the usual $\mathrm{EC}_{50}$ value. This was because $\mathrm{EC}_{10}$ and $\mathrm{EC}_{20}$ concentrations were much closer to possible environmental concentrations of the chemicals under study. The general order of toxicities was: atrazine $>$ CEAT $>$ CIAT. The toxicity of atrazine remained stable over time, whereas the toxicities of CEAT and CIAT decreased over longer testing times. ${ }^{28}$

\section{Plant Toxicity}

Crops such as corn, sorghum, and sugar cane are tolerant of atrazine, a broad-leaf herbicide, because they are able to biochemically degrade the herbicide to its nontoxic metabolites. ${ }^{30}$ The toxicity of atrazine and its metabolites were compared in one plant study. Dealkylation products, such as CIAT and CEAT, were found to remain somewhat toxic. ${ }^{29}$ In another study of a fungus (Cochliobolus Sativus), atrazine inhibited germination of conidia, but OIET was found to act as a germination stimulant, possibly even lethally over stimulating the organisms. ${ }^{31}$ The authors of the fungus study report previously unpublished data which suggest that several common degradation products of atrazine (other than OIET) inhibit germination of the conidia, but the degradation products are not identified specifically. 


\section{Conclusions}

In the studies reviewed in this report, in general, atrazine was reported to be more toxic than its degradation products. Atrazine has been reported to have higher chronic toxicity than CIAT towards rat endocrine activity. The degradation product CAAT was less toxic than the $s$-triazine ring towards birds. For phototrophic microorganisms, the order of toxicity from high to low was: atrazine $>$ CIAT $>$ CEAT. The degradation products OIET and CAAT were found to be nontoxic towards most phototrophic microorganism cultures tested. The Microtox test of bacterial toxicity also showed that atrazine was more toxic than its degradation products with the order of toxicity from high to low reported as: atrazine $>$ CEAT $>$ CIAT.

Of particular interest for the $\mathrm{TiO}_{2}$ photocatalytic project is a comparison of the toxicity of the starting compound, atrazine, with the final degradation product, cyanuric acid (OOOT). Mammalian $\mathrm{LD}_{50}$ 's for both of these compounds have been established. Atrazine $\left(\mathrm{LD}_{50} 3.0 \mathrm{~g} / \mathrm{kg}\right)$ is more than twice as toxic as cyanuric acid $\left(L_{50} 7.7 \mathrm{~g} / \mathrm{kg}\right)$.

In conclusion, based on the literature currently available, it appears that any degradation of atrazine results in less toxic products. Complete degradation of atrazine to cyanuric acid, which can be accomplished using $\mathrm{TiO}_{2}$ photocatalysis, decreases the toxicity of the waste stream to less than half its original toxicity.

Whereas atrazine is considered to be moderately toxic, cyanuric acid has been classified as practically nontoxic by Hammond and coworkers. The degradation of atrazine to cyanuric acid would, therefore, represent a significant toxicological risk reduction for atrazine-contaminated waters. 


\section{Part 2: Physical Properties of Atrazine and Its Degradation Products}

The physical properties of atrazine and its degradation products which will be discussed in this section include melting point, molecular weight, vapor pressure, solubility, and pKa's. Sources for UV, IR, and mass spectral data are reported. The soil half-lives for atrazine, CIAT, and CEAT are compared to the $\mathrm{TiO}_{2}$ photocatalytic half-lives for the same compounds.

\section{Melting Point and Molecular Weight}

The melting point and molecular weight of atrazine and thirteen degradation products are shown in Table VII.

Vapor pressure and solubilities of atrazine and nine of its degradation products are given in Table VIII.

In Table IX, the pKa's of atrazine and its degradation products are shown. A schematic of the dissociation in question is shown below: ${ }^{41}$<smiles>[X]c1nc(NCC)nc(=[NH+]C(C)C)[nH]1</smiles><smiles>[X]c1nc(NCC)nc(NC(C)C)n1</smiles>

If $\mathrm{X}=\mathrm{Cl}, \mathrm{pKa}=\sim 2$

If $\mathrm{X}=\mathrm{OH}, \mathrm{pKa}=\sim 5$

A comparison of the soil half-lives and $\mathrm{TiO}_{2}$ photocatalytic half-lives for atrazine, CIAT, and CEAT are given in Table XI. This data was included to give a comparison of the degradation rates for atrazine with the degradation rates of its intermediates by $\mathrm{TiO}_{2}$ photocatalysis. ${ }^{22} \mathrm{The}^{2}$ predominant soil metabolite of atrazine was found to be CLAT. ${ }^{55}$ CIAT was also found to be more mobile in soils than atrazine whereas CEAT was found to have about the same soil mobility as atrazine. 27,28 The soil degradation of atrazine is greatly influenced by low $\mathrm{pH}$, mineral salts, organic matter and photolysis. ${ }^{32}$ 
Table VII. Melting Point and Molecular Weight of Atrazine and Thirteen of Its Degradation Products

\begin{tabular}{|c|c|c|}
\hline Compound & Melting point $\left({ }^{\circ} \mathrm{C}\right)$ & Molecular weight \\
\hline 1. Atrazine & $175-177^{b, d}$ & 215.7 \\
\hline 2. OOOT & $>360^{a}$ & 129.1 \\
\hline 3. CEAT & $164-166^{b}$ or $177-179 c$ & 173.6 \\
\hline 4. CIAT & $132-134^{d}$ or $42-50^{b}$ & 187.6 \\
\hline 5. OIAT & $>310^{b}$ & 169.2 \\
\hline 6. CAAT & $320^{d}$ & 145.6 \\
\hline 7. OAAT & $>320$ & 127.1 \\
\hline 8. OOAT & NA & 128.1 \\
\hline 9. OIET & $>310^{d}$ or $>250^{e}$ & 197.2 \\
\hline 10. CDAT & $225(\mathrm{dec} .)^{\mathrm{f}}$ & 187.6 \\
\hline 11. CDIT & $\begin{array}{l}177-178^{f} \text { or } \\
187-188 \mathrm{~g}\end{array}$ & 229.7 \\
\hline 12. CDET & $180-181^{f}$ & 215.6 \\
\hline 13. CDDT & $197-198^{f}$ & 229.6 \\
\hline 14. COAT & NA & 146.5 \\
\hline 15. COOT & NA & 147.5 \\
\hline 16. MEIT & $95-96^{d}$ & 211.3 \\
\hline
\end{tabular}

NA: Not Available

aThe Merck Index reports that cyanuric acid does not melt, it evolves cyanic acid on heating. ${ }^{17}$

bFrom Ciba-Geigy MSDS

cSee Reference 33

dFrom Chem Service, Inc. MSDS

e Reference 34 reports OIET decomposes without melting at $>250^{\circ} \mathrm{C}$

fSee Reference 5

gSee Reference 35 
Table VIII. Vapor Pressure and Solubility of Atrazine and Nine of Its Degradation Products

$\begin{array}{lll}\text { Compound } & \text { Vapor pressure }(\mathrm{mm} \mathrm{Hg}) \quad \text { Solubility }\end{array}$

1. Atrazine $\quad 6.6 \times 10^{-7}\left(\text { at } 25^{\circ} \mathrm{C}\right)^{\mathrm{a}}$
$3 \times 10^{-7}\left(\text { at } 20^{\circ} \mathrm{C}\right)^{\mathrm{b}, \mathrm{c}}$

2. OOOT

3. CEAT

4. CIAT

NA

NA

$3 \times 10^{-7}\left(\text { at } 20^{\circ} \mathrm{C}\right)^{b}$

NA

$3 \times 10^{-7}\left(\text { at } 20^{\circ} \mathrm{C}\right)^{b}$

NA

NA

9. OIET
$33 \mathrm{ppm} / \mathrm{H}_{2} \mathrm{O} / 22^{\circ} \mathrm{C}^{\mathrm{a}, \mathrm{e}, \mathrm{f}}$

$31 \mathrm{ppm} / \mathrm{pH} 3.0 \mathrm{~g}$

$34.7 \mathrm{ppm} / \mathrm{pH} 7.0 \mathrm{~g}$

$36.7 \mathrm{ppm} / \mathrm{pH} 10.0 \mathrm{~g}$

$1800 \mathrm{ppm} / \mathrm{MeOH} / 27^{\circ} \mathrm{C}$

$52 \mathrm{ppm} / \mathrm{CHCl}{ }_{3} / 27^{\circ} \mathrm{C}$

$>6470 \mathrm{ppm} / \mathrm{EtOH}$

$2600 \mathrm{ppm} / \mathrm{H}_{2} \mathrm{O}^{d}$

$2967 \mathrm{ppm} / \mathrm{H}_{2} \mathrm{O}^{\mathrm{e}}$

$3200 \mathrm{ppm} / \mathrm{MeOH}^{\mathrm{d}}$

$6000 \mathrm{ppm} / \mathrm{THF}^{\mathrm{d}}$

10,200 ppm/1,4-Dioxane ${ }^{d}$

$>114 \mathrm{ppm} / \mathrm{H}_{2} \mathrm{O}$

$>1533$ ppm/MeOH

$>\sim 438 \mathrm{ppm} / \mathrm{H}_{2} \mathrm{O}$

$375 \mathrm{ppm} / \mathrm{H}_{2} \mathrm{O}^{\mathrm{e}}$

$>5867 \mathrm{ppm} / \mathrm{MeOH}$

NA

NA

$76.2 \mathrm{ppm} / \mathrm{H}_{2} \mathrm{O}^{\mathrm{e}}$

$762 \mathrm{ppm} / 0.1 \underline{\mathrm{M} \mathrm{HCl}}$

$76.8 \mathrm{ppm} / \mathrm{H}_{2} \mathrm{O}^{\mathrm{e}}$

$1280 \mathrm{ppm} / 0.1 \underline{\mathrm{M}} \mathrm{NaOH}$

NA: not available

aCiba-Geigy MSDS

$\mathrm{b}_{\text {Chem Service MSDS }}$

cSee Reference 36; the data was converted from $\mathrm{Pa}$ to $\mathrm{mm} \mathrm{Hg}$.

dSee Reference 37

esee Reference 38

fSee Reference 39

gSee Reference 40 
Table IX. pKa's for Atrazine and Its Derivatives

\begin{tabular}{lll}
\hline Compound & $\mathrm{pKa}^{1}$ & $\mathrm{pKa}^{2}$ \\
\hline 1. Atrazine & $\begin{array}{l}1.71^{\mathrm{a}} \\
1.85^{\mathrm{b}} \\
1.68^{\mathrm{c}}\end{array}$ & \\
& $6.51^{\mathrm{d}}$ & $10.60^{\mathrm{d}}$ \\
2. OOOT & & \\
3. CEAT & $1.58^{\mathrm{a}}$ & \\
4. CIAT & $1.65^{\mathrm{a}}$ \\
5. OIAT & $4.57^{\mathrm{a}}$ \\
6. OEAT & $4.65^{\mathrm{a}}$ \\
7. CAAT & \\
8. OAAT & \\
9. OOAT & \\
10. OIET & \\
11. COAT & \\
12. COOT & $5.15^{\mathrm{a}}$ \\
\hline
\end{tabular}

asee Reference 41

bSee Reference 42

cSee Reference 43

dSee Reference 37

eThe dissociation constant for the hydroxy group on the hydroxyatrazines is about 11.41 
Table X. UV, IR, and Mass Spec Data Sources

\begin{tabular}{llll}
\hline Compound & UV & IR & Mass spec \\
\hline 1. Atrazine & 41 & 44 & \\
2. OOOT & 45 & $46,47,48,49$ & 52 \\
3. CEAT & 41 & 50,51 & \\
4. CIAT & 41 & 50 & \\
5. OIAT & 41 & & 52 \\
6. OEAT & 41 & & 47 \\
7. CAAT & & 49,53 & \\
8. OAAT & 54 & 49 & \\
9. OOAT & & 47,49 & \\
\hline
\end{tabular}

Table XI. Half-Lives for Atrazine and Its Degradation Products in Soil and During $\mathrm{TiO}_{2}$ Photocatalysis

\begin{tabular}{llccc}
\hline Name & $\mathrm{TiO}_{2}$ half life & Reference & Soil half-life & Reference \\
\hline Atrazine & 4 hours & 22 & $0.5-6$ months & 55 \\
CEAT & 4.8 hours & 22 & 5 months & 27 \\
CIAT & 6 hours & 22 & $>5$ months & 27 \\
\hline
\end{tabular}




\section{References}

1 (a)Sullivan, J. M.; Grinstead, J. H., Jr.; Gautney, J.; Salladay, D. G. Chemical Research Department Progress Report No. CRD 92-10, 1992, Tennessee Valley Authority, Muscle Shoals, Alabama. (b) Kiserow, D. J.; Grinstead, J. H., Jr.; Sullivan, J. M.; Gautney, J. Chemical Research Department Progress Report No. CRD 92-19, 1992, Tennessee Valley Authority, Muscle Shoals, Alabama. (c) Grinstead, J. H., Jr.; Sullivan, J. M.; Gautney, J. Chemical Research Department Progress Report No. CRD 93-1, 1993, Tennessee Valley Authority, Muscle Shoals, Alabama. (d) Sullivan, J. M.; Grinstead, J. H., Jr.; Gautney, J. Chemical Research Department Progress Report No. CRD 93-3, 1993, Tennessee Valley Authority, Muscle Shoals, Alabama. (e) Kiserow, D. J.; Gautney, J. Chemical Research Department Progress Report No. CRD 93-6, 1993, Tennessee Valley Authority, Muscle Shoals, Alabama. (f) Kiserow, D. J.; Gautney, J. Chemical Research Department Progress Report No. CRD 93-8, 1993, Tennessee Valley Authority, Muscle Shoals, Alabama. (g) Pugh, K. C.; Kiserow, D. J.; Gautney, J. Chemical Research Department Progress Report No. CRD 93-9, 1993, Tennessee Valley Authority, Muscle Shoals, Alabama. (h) Kiserow, D. J.; Gautney, J. Chemical Research Department Progress Report No. CRD 93-15, 1993, Tennessee Valley Authority, Muscle Shoals, Alabama. (i) Pugh, K. C.; Gautney, J. Chemical Research Department Progress Report No. CRD 93-19, 1993; Tennessee Valley Authority, Muscle Shoals, Alabama. (j) Pugh, K. C.; Kiserow, D. J.; Gautney, J. Chemical Research Department Progress Report No. CRD 93-20, 1993; Tennessee Valley Authority, Muscle Shoals, Alabama. (k) Kiserow, D. J.; Pugh, K. C.; Gautney, J. Chemical Research Department Progress Report No. CRD 93-21, 1993; Tennessee Valley Authority, Muscle Shoals, Alabama.

2 Pelizzetti, E.; Maurino, V.; Minero, C.; Carlin, V.; Pramauro, E.; Zerbinati, O.; Tosato, M. L. Environ. Sci. Technol. 1990, 24, 1559.

3. Cook, A. M.; Beilstein, P.; Grossenbacher, H.; Hütter, R. Biochem. J. 1985, 231, 25.

4. Adams, C. D.; Randtke, S. J. Environ. Sci. Technol. 1992, 26, 2218.

5. Hapeman-Somich, C. J.; Gui-Ming, Z.; Lusby, W. R; Muldoon, M. T.; Waters, R. J. Agric. Food Chem. 1992, 40, 2294.

6 Professional Analytical Consultants, Inc. (PACS), Coraopolis, PA, (412) 457-6576.

7 Sittig, M. Handbook of Toxic and Hazardous Chemicals and Carcinogens, 3rd. ed; Noyes: New Jersey, 1991; Vol. 1, p.177.

8 MSDS from Aldrich, from data in RTECS

9 Ammelide is also a synonym for the compound melamine (AAAT). The ammelide discussed in this work is not the same compound as melamine.

10 MSDS from Chem. Service, Inc., West Chester, PA 
11 National Library of Medicine, Registry of Toxic Effects of Chemical Substances (RTECS). Maintained by the National Library of Medicine, supported by a contract with Chemical Abstracts Services (CAS), and available through MEDLARS system.

12 "Final Report on the Developmental Toxicity of California Pesticide/Fertilizer Mixture in Sprague-Dawley (CD) Rats: Laboratory Supplement," National Toxicology Program, National Institute of Environmental Health Sciences, Research Triangle Park, NC 27709, February, 1992

13 Neskovic, N. K.; Elezovic, I.; Karan, V.; Poleksic, V.; Budimir, M. "Acute and Subacute Toxicity of Atrazine to Carp (Cyprinus carpio L.)," Ecotoxicology and Environmental Safety, 1993, 25, 173-182.

14. Hammond, B. G.; Barbee, S. J.; Inoue, T.; Ishida, N.; Levinskas, G. J.; Stevens, M. W.; Wheeler, A. G.; Cascieri, T. "A Review of Toxicology Studies on Cyanurate and its Chlorinated Derivatives," Environmental Health Perspectives, 1986, 69, 287-292.

15 Mazaev, V. T. "Experimental Determination of the Maximum Permissible Concentrations of Cyanuric Acid, Monosodium Salt of Cyanuric Acid, Simazine, and a 2-Hydroxy Derivative of Simazine in Water Resevoirs," Sanit. Okhr. Vodoemov Zagryazneniya Prom. Stochnymi Vodami., 1964, 6, 229-250.

16 Inokuchi, N.; Sawamura, R.; Hasegawa, A.; Urakubo, G. "Distribution, percutaneous absorption and excretion of cyanuric acid," Eisei Kagaku, 1978, 24, 49-59.

17 The Merck Index, 11th ed.; Budavari, S., Ed.; Merck \& Co.: Rahway, NJ, 1989; p. 2708

18 Canelli, E. "Chemical, Bacteriological, and Toxicological Properties of Cyanuric Acid and Chlorinated Isocyanurates as Applied to Swimming Pool Disinfection: A Review," Am.J. Public Health, 1974, 64, 155.

19 Mazaev, V. T. "Maximum Permissible Concentration of Cyanuric Acid and Its Monosodium Salt in Water Supplies," Gig. Sanit., 1962, 27, 13-19.

20 Pliss, G. B.; Zabezhinskii, M. A. "Carcinogenic Properties of s-Triazine Derivatives," Vopr. Onkol., 1970, 16, 82-85.

21 Barbee, S. J.; Cascieri, T.; Hammond, B. G.; Inoue, T.; Ishida, N.; Wheeler, A. G.; Chadwick, M.; Hayes, D.; Macauley, J.; McComish, A. "Metabolism and disposition of sodium cyanurate," Toxicologist, 1983, 3, 80.

22 Pugh, K. C.; Kiserow, D. J.; Gautney, J. The Long-Term Photocatalytic Degradation of Atrazine, Chemical Research Department Progress Report CRD 93-20, 1993, Tennessee Valley Authority, Muscle Shoals, Alabama.

23 (a) Marchini, S.; Passerini, L.; Cesareo, D.; Tosato, M.L. "Application of Structure-Activity Analysis for Estimation of Potential Effects of Pesticides on Environmental Biological Targets," NATO ASI Series, 1987, Vol. H13, 285-290, and (b) Tosato, M. L.; Cesareo, D.; 
Marchini, S.; Passerini, L.; Pino, A. "QSARs and Pesticide Design" QSAR: Quantitative Structure-Activity Relationships in Drug Design, 1989, pp 417-420, Alan R. Liss, Inc.

24 Kniewald, J.; Peruzovic, M.; Gojmerac,T.; Milkovic, K.; Kniewald, Z. "Indirect influence of s-triazines on rat gonadotropic mechanism at early post-natal period." J. Steroid Biochem., 1987, 27, 1095-1100.

25 Babic-Gojmerac, T.; Kniewald, Z.; Kniewald, Z. "Testosterone metabolism in neuroendocrine organs in male rats under atrazine and deethylatrazine influence," J. Steroid Biochem., 1989, 33, 141-146.

26 Schafer, E. W., Jr., Bowles, W. A., Jr.; Hurlbut, J. "The Acute Oral Toxicity, Repellency, and Hazard Potential of 998 Chemicals to One or More Species of Wild and Domestic Birds," Arch. Environm. Contam. Toxicol., 1983,12, 355-382.

27 Stratton, G. W. "Effects of the Herbicide Atrazine and its Degradation Products, Alone and in Combination, on Phototrophic Microorganisms," Arch. Environ. Contam. Toxicol,. 1984, $13,35-42$.

28 Kross, B. C.; Vergara, A.; Raue, L. E. "Toxicity Assessment of Atrazine, Alachlor, and Carbofuran and Their Respective Environmental Metabolites Using Microtox," J. Toxicol. Environ. Health, 1992, 37(1), 149-159.

29 Shimabukuro, R. H. "Atrazine metabolism and herbicidal selectivity," Plant Physiology 1968, 42, 1269-1276.

30 Jensen, K. I. N.; Stephenson, G. R.; Hunt, L. A. "Detoxification of Atrazine in Three Gramineae Subfamilies," Weed Science, 1977, 25 (3), 212-220.

31 Isakeit. T.; Lockwood, J. L. "Abiotic Soil Factors Influencing the Deleterious Effect of Atrazine on Ungerminated Conidia of Cochliobolus Sativus, "Soil Biol. Biochem., 1990, 22 (1), 35-41.

32 Behki, R. M. and Kahn, S. U. "Degradation of atrazine by Pseudomonas: N-Dealkylation and dehalogenation of atrazine and its metabolites, "J. Agric. Food Chem., 1988, 34, 746749.

33 Pearlman, W. M.; Banks, C. K. "Substituted Chlorodiamino-s-triazines," J. Am. Chem. Soc., $1948,70,372$

34 Pape, B. E.; Zabik, M. J. "Photochemistry of Bioactive Compounds," J. Agr. Food Chem., 1970, 18(2), 202-207.

35 Rejto, M.; Saltzman, S.; Acher, A. J.; Muszkat, L. "Identification of Sensitized Photooxidation Products of s-Triazine Herbicide in Water," J. Agric. Food Chem., 1983, 31, 138-142.

36 The Pesticide Manual; Worthing, C. R., Ed.; 6 ed., 1979; OECD. 
37 Belaj, F.; Tripolt, R.; Nachbaur, E. "Kristallstruktur und thermisches Verhalten der Additionsverbindungen von Trithiocyanursaure mit Tetrahydrofuran und 1,4-Dioxan," Monatshefte fur Chemie, 1990, 121, 99-108.

38 Beilstein, P.; Cook, A. M.; Hutter, R. "Determination of Seventeen s-Triazine Herbicides and Derivatives by High-Pressure Liquid Chromatography," J. Agric. Food Chem., 1981, 29, 1132.

39 Esser, H. O.; Dupuis, G.; Ebert, E.; Marco, G. J.; Vogel, C. In Herbicides: Chemistry, Degradation and Mode of Action; 2nd ed.; Keamey, P. C.; Kaufman, D. D., Eds.; Marcel Dekker: New York, 1975; Vol. I, Chapter 2.

40 Ward, T. M.; Weber, J. B. "Aqueous Solubility of Alkylamino-s-triazines as a Function of pH and Molecular Structure," J. Agric. Food Chem., 1968, 16(6), 959-961.

41 Vermeulen, N. M. J.; Apostolides, Z.; Potgieter, D. J. J.; Nel, P. C.; Smit, N. S. H. "Separation of atrazine and some of its degradation products by high performance liquid chromatography," J. Chromatogr., 1982, 240, 247-253.

42 Weber, J. B. Spectrochim. Acta, 1967, 23A, 458.

43 Jordan, L. S. Residue Rev., 1970, 32, VII.

44 The Aldrich Library of Infrared Spectra, 3rd ed.; Charles J. Pouchert, Ed.; Aldrich: Milwaukee, WI, 1981; $1381 \mathrm{H}$.

45 Cignitti, M.; Paoloni, L. "Tautomeric Forms of Oxy- and Oxo-Derivatives of 1,3,5-Triazine. Il The Ultraviotel Absorption of 2,4,6-Trimethoxy-1,3,5-Triazine and 2,4,6-Trioxo-1,3,5Trimethylhexahydrotriazine," Spectrochim. Acta, 1964, 20, 211-218.

46 The Aldrich Library of Infrared Spectra, 3rd ed.; Charles J. Pouchert, Ed.; Aldrich: Milwaukee, WI, 1981; 1380 G.

47 Bieling, H.; Raduchel, M.; Wenzel, G.; Beyer, H. "Uber Cyanmelamin und Cyanammelin," $J$. Prak. Chem., 1965, 28, 325-340.

48 Cignitti, M.; Paoloni, L. Tautomeric Forms of Oxy-Derivatives of 1,3,5-Triazine. I," Rend. 1st Super. Sanita, 1960, 23, 1037-1047.

49 Padgett, W. M.; Hamner, W. F. "The Infrared Spectra of Some Derivatives of 1,3,5Triazine" J. Am. Chem. Soc., 1958, 80, 803-808.

50 Shimabukuro, R. H.; Kadunce, R. E.; Frear, D. S. "Dealkylation of Atrazine in Mature Pea Plants," J. Agr. Food Chem., 1966, 14, 392-395.

51 Kearney, P. C.; Kaufman, D. D.; Sheets, T. J. "Metabolites of Simazine by Aspergillus," J. Agric. Food Chem., 1965, 13, 369. 
52 Ross, J. A.; Tweedy, B. G. "Mass Spectra of Chloro-, Aminochloro- and Ethylaminochloros-triazines," Organic Mass Spectrometry, 1970, 3, 219-229.

53 The Aldrich Library of Infrared Spectra, 3rd ed.; Charles J. Pouchert, Ed.; Aldrich: Milwaukee, WI, 1981; 1381F.

54 Mushkin, Y. I.; Finkel'shtein, A. I. "Transfromations of (Cyanoamidino) Urea in Alkaline and Acid Solutions. 1,3-Dicarbamoylguanidine," J. Org. Chem. USSR, 1967, 3, 486-489.

55 U.S. Environmental Protection Agency, Health Advisory: Atrazine., 1987, Washington, D.C.: U.S. EPA. 